\title{
Factors Shaping efl Preservice Teachers' IDENTity Configuration
}

\author{
FACTORES QUE DETERMINAN LA CONFIGURACIÓN DE LA IDENTIDAD EN DOCENTES \\ DE INGLÉS EN FORMACIÓN
}

FACTEURS FAÇONNANT L'IDENTITÉ DES ENSEIGNANTS D'ANGLAIS EN FORMATION

\author{
Ximena Paola Buendía-Arias \\ Magíster en Enseñanza del Inglés, \\ Tianjin Foreign Studies University, \\ China. \\ Docente de planta, Universidad de \\ Sucre, Colombia. \\ ximena.buendia@unisucre.edu.co \\ https://orcid. \\ org/0000-0003-3993-7557
}

\section{Andrea André-Arenas \\ Magíster en Enseñanza del Inglés, Universidad del Norte, Colombia. Investigadora independiente, Colombia. \\ andrea_andre@hotmail.com https://orcid. org/0000-0003-2635-9145}

\author{
Nayibe del Rosario \\ Rosado-Mendinueta \\ Ph. D. en Educación, Universidad del \\ Atlántico, Colombia. \\ Docente tiempo completo, \\ Universidad del Norte, Colombia. \\ nrosado@uninorte.edu.co \\ https://orcid. \\ org/0000-0003-1865-2464
}

\begin{abstract}
Preservice EFL teachers face many challenges when developing their practicum. Such an experience shapes their identity and influences the teaching and learning processes. This descriptive case study is about preservice teachers' identity formation and the factors that shaped their identity configurations during a practicum course offered at a state university in Colombia. Data, collected through interviews, reflective journals, and drawing-derived metaphors were analyzed using thematic analysis. The results identified participants' value/belief system, personality traits, context, pedagogical decisions, reflective practice, and critical incidents as influential factors in their identity formation process. The findings also revealed that identity can be constructed through the intersection between the different experiences they go through during their practicum and their past and future trajectories. The study suggests that EFL teacher education programs should take explicit pedagogical actions to incorporate the identified factors in their curriculum. This could strengthen EFL preservice teachers' identity configurations and prepare them better for their future teaching roles.
\end{abstract}

Keywords: practicum; teachers' identity; EFL; identity; preservice teachers.

\section{RESUMEN}

Los docentes de inglés en formación se enfrentan a muchos retos al desarrollar su práctica. Tal experiencia forma su identidad e influye en los procesos de enseñanza y aprendizaje. Este estudio de caso descriptivo trata de la formación de la identidad de un grupo de docentes en formación y de los factores que dieron forma a las configuraciones de la identidad durante su primer período de práctica en una universidad estatal de Colombia. Los datos, recogidos mediante entrevistas, diarios de reflexión y metáforas derivadas de dibujos, se analizaron mediante un análisis temático. Los resultados identificaron el sistema de valores/creencias de los participantes, los rasgos de personalidad, el contexto, las decisiones pedagógicas, la práctica reflexiva y los incidentes críticos como factores influyentes en el proceso de formación de su identidad. Los resultados también revelaron que la identidad puede construirse a través de la intersección entre las diferentes experiencias por las que pasan los docentes en formación durante su práctica y sus trayectorias pasadas y futuras. El estudio sugiere que los programas de formación de profesores de inglés deberían tomar acciones pedagógicas explícitas para incorporar los factores identificados en su currículo. Esto podría fortalecer las configuraciones de la

Received: 2019-07-13 / Accepted: 2020-03-20 / Published: 2020-09-17

https://doi.org/10.17533/udea.ikala.v25n03a02 
identidad de los docentes de inglés en formación y prepararlos mejor para su función docente.

Palabras claves: práctica; identidad del profesor; ILE; identidad; docentes en formación.

\section{RÉSUMÉ}

Les professeurs EFL en formation font face à beaucoup de défis lors de leur stage pratique. Cette expérience forme leur identité et influence leur processus d'apprentissage et d'enseignement. Cette étude de cas descriptive porte sur la formation d'identité des professeurs en formation et des facteurs qui construisent leurs éléments d'identité pendant un stage offert dans une université publique en Colombie. Les données ont été recueillies au moyen d'entretiens, de journaux de réflexions et de métaphores issues de dessins, et ensuite analysées selon une grille thématique. Les résultats ont montré que le système de valeurs et croyances des participants, les traits de personnalité, le contexte, les décisions pédagogiques, la pratique réflexive et les incidents critiques sont autant des facteurs qui influencent le processus de la construction de leur identité. Ces résultats montrent que la construction de leur identité peut être le resultat du croisement entre les différentes expériences vécues au cours de leur stage pédagogique et de leurs trajets personnels passés et futurs. L'étude suggère que les programmes de formation de professeurs en anglais, devrait prendre des actions pédagogiques explicites pour intégrer les facteurs identifiés dans leurs programmes. Ceci pourrait renforcer les éléments de construction d'identité des professeurs stagiaires d'anglais langue étrangère et mieux les préparer à leur rôle futur.

Mots-clés : stage pédagogique ; identité de l'enseignant ; ALE ; identité ; enseignants stagiaires. 


\section{Introduction}

Professional identity is a concept that has been of great interest to teacher educators and researchers. The trend in the ELT community is changing the focus from educating teachers with teaching strategies to educating them as critical practitioners who are politically aware and actively involved in social justice-oriented teaching to help transform society (Kumaravadivelu, 2012; Kohli et al., 2015). To achieve this aim, language teacher education programs are called to stop divorcing their curriculum and teaching practices from teacher candidates' identities and local knowledge (Mahboob, 2016). However, and as reported by Guerrero and Meadows (2015), some teacher education programs fall short in educating teachers with the "awareness that any teaching context is situated at both global and local scales" (p. 14). Likewise, there are concerns about how teacher education responds to the challenges presented by the legacy of colonialism that has left countries with imposed top-down language policies and by teachers' consumerist attitudes towards foreign theories, approaches, and methods; the latter, at the expense of local contexts and their embedded sociocultural features, individuals' beliefs, knowledge, and experiences (Shohamy, 2009; Quintero \& Guerrero, 2013).

In Colombia, the ELT community has attempted to understand what is happening within foreign language teacher education programs in relation to teacher identity. Studies in our context indicate language teacher education programs focus on theoretical knowledge, decontextualized practices, and established international standards, at the cost of novice teachers' pre-existing beliefs, experiences, backgrounds, and personalities (Castellanos, 2013; Fajardo, 2014; Quintero, 2016; Suárez \& Basto, 2017; Castañeda \& Aguirre, 2018). Data from these studies suggest that language teacher education programs have assumed an underlying view of teacher knowledge "that is molecular and fragmented, not designed to develop a holistic view of knowing, doing, or understanding" (Clift \& Brady, 2005, p. 310). Once in the classroom, language preservice teachers (PSTS) "forget or misuse the information acquired during their education" (Castellanos, 2013 , p. 198) or "gradually [adopt] the same practices [of the veterans around them]" (Akcan, 2016, p. 56). Initial experiences in the practicum are far from ideal, and feelings of unpreparedness to face their local classrooms arise (Macías \& Sanchez, 2015), affecting their identity during this stage of their education and impacting their future trajectories as teachers.

Studies in Colombia have paid attention to the formation of foreign language teachers' identity through the exploration of their preexisting beliefs, values, self-images, prior learning experiences and their connection to the local context (Arrieta \& Rosado, 2020; Fajardo, 2014; Guerrero \& Meadows, 2015; Pinzón \& Guerrero, 2018; Quintero, 2016). Arrieta and Rosado's research (2020) has focused on how identity/identities are negotiated during ongoing interaction in the classroom. Quintero's research (2016) has shown the connection between life stories and the formation of English teachers, highlighting the potential to become "transformative intellectuals" or "reflective practitioners" (Kumaravadivelu, 2012, p. 11) rather than just "passive technicians." Izadinia (2013) suggests that understanding how language preservice teacher professional identity develops over the course of a teacher education program will assist teacher educators to better prepare language preservice teachers for the rigors of teaching and may shed light on how to engage them in "a productive process of constructing their professional identities” (p. 695). In keeping with the author's observations, interest in examining identity during language preservice education recognizes that the teaching profession is about self-discovery, transformation and evolution.

As discussed in the literature in the field, the configuration of identity is a complex process. 
Morrison (2012) has highlighted this complexity and states that identity is a dynamic, changing, and multifaceted concept; authors such as Akkerman and Meijer (2011), Beijaard et al. (2004) and Varghese et al. (2005) have also underlined the fact that identity is responsive to and reflective of the contexts in which it is developed. It may seem evident that getting an in-depth understanding of how language preservice teachers' professional identity emerges and evolves during the practicum experience is necessary to enhance such experience. Our interest resides in examining identity during the practicum of foreign language PSTs as we acknowledge that identity is strongly shaped at that moment.

This study is therefore interested in examining the factors that influence the identity configuration of Foreign Language (FL) preservice teachers during their practicum in a teacher education program in a Colombian state university. By researching and reflecting upon their identity formation in this specific context, we expect to contribute to local, national and international scholarship in this field.

\section{Theoretical Framework}

As teacher identity research has developed over time, the concept of identity has been used to reference different ideas, frameworks and factors contributing to our understanding of how teachers configure their professional identity. The sections that follow locate the study within relevant developments.

\section{Identity}

The concept of identity is framed within the postmodern view that defines identity as "something that is actively constructed on an ongoing basis" deploying it as "fragmented, not unified; multiple, not singular; expansive, not bounded" (Kumaravadivelu, 2012, p. 10). In a similar vein, for Rodgers and Scott (2008) identity is formed within multiple contexts, involves relationships and emotions, and allows for the construction and reconstruction of meaning through stories over time. As suggested by these authors, the context plays an important role in identity construction along with relationships forged and the feelings experimented during the process. The exploration of FL preservice teachers coming to terms with becoming teachers should be framed in the local context, aiming to unveil inner and outer forces that configure their teacher identity.

\section{Teacher Identity Frameworks}

Teaching identity construction is an intersection of the personal and the professional. For this research, the personal ideologies as well as the professional expectations were explored to comprehend how the "teacher persona" is constructed. As depicted in Figure 1, we used three complementary frameworks to evidence the emergence of preservice teachers' identities.

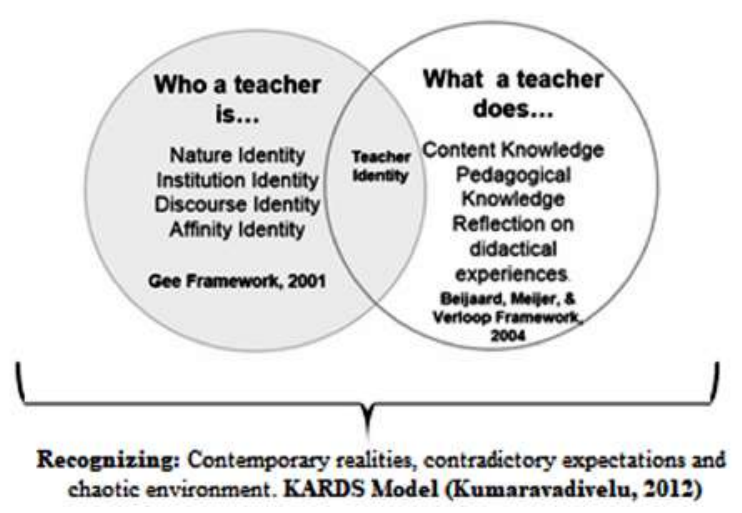

Figure 1 The Concept of Identity: Intersecting Frameworks

Note. The concept of identity used in this investigation intersects three existing frameworks: (a) Teacher as a person (Gee, 2001); (b) Teacher's knowledge, skills, and performance in the classroom (Beijaard et al, 2004); and (c) Identity based on the recognizing element suggested by Kumaravadivelu (2012).

In this study, the term "teaching identity" comprises what a teacher is and what a teacher does. Gee poses that all people have "multiple identities connected not only to their 'internal states' but to their performances in society" (as cited in Lerseth, 2013, p. 99). His framework proposes four identity categories, namely N-Identity (identification 
of biological factors), I-Identity (institutional related identity features), D-Identity (individual traits, achievements and attributes and A-Identity (features of identity that reflect groups with whom people share common interests). The framework by Beijaard et al. (2004) describes identity in terms of the factors influencing what a teacher does by determining how they see themselves regarding three areas: content knowledge, pedagogical decisions, and didactical experiences. Content knowledge is defined as the extent a teacher understands their own subject area determining teacher effectiveness. Pedagogical knowledge refers to the balance between the teacher's pedagogical and didactic competences. Didactical experiences pertain to reflected decisions teachers make in the classroom in terms of what works and what does not work allowing them to advance not only in their content knowledge but also in their pedagogical skills.

The framework by Kumaravadivelu, called KARDS (2012), operates on three principles: (particularity, practicality and possibility), and is based on five elements (Knowing, Analyzing, Recognizing, Doing and Seeing). All of the elements are interconnected and provide insights based on intensive reflection for teachers to become critical practitioners. For Kumaravadivelu (2012), “teachers' identity formation, then, resides largely in how they make sense of the contemporary realities, and how they negotiate contradictory expectations, and how they derive meaning out of a seemingly chaotic environment" (p. 58). Our framework aligns with the postmodern view of identity as it considers the being, the doing, and the inner self of the teacher. We think the teaching identity is embedded within the persona, the acting and the values brought within in a particular context. In this study, we attempted to consider these multiple layers.

\section{Factors influencing professional identity}

Authors such as Bucholtz and Hall (2005), Chong et al. (2011), and Korthagen (2004) have highlighted the different elements that affect the process of constructing a professional identity, namely implicit beliefs and identities about students, the teaching subject, and teaching role and responsibilities. Similarly, enrollment in professional communities of practice appear to help teachers reflect, construct and adopt identity positions for themselves (Bucholtz \& Hall, 2005).

In the same vein, Morrison (2013) highlights influences deriving from background and experiences, communities of practice, dynamics of professional identity formation, emerging subjective feelings and dispositions, existent of attributes or resources within the individual, critical incidents experienced, assessments made of themselves as emergent professionals, and interpersonal supports. These aspects "allow for exploration of understandings [and provide] opportunities for the participants to guide discussion towards personally relevant and meaningful insights" (Richards, 2009, p. 122).

Reflection and critical incidents also affect identity formation. Reflective practices "help preservice teachers to consciously direct the development of their personal identity, their inspiration and enthusiasm for their profession" (Korthagen, 2004, p. 91) enabling them to look within themselves and within their own courses (Murphy, 2001). Reflective thinking can be promoted with journal writing (Ho \& Richards, 2008; Insuasty \& Zambrano, 2010), which facilitates teachers' insights into theories of teaching, approaches and methods, evaluating teaching, selfawareness, and questions about teaching.

Critical incidents (CI) are "a form of movement that involves revisions in identity and agentic affiliations" (O'Shea, 2014, p. 5). Measor defines CI as, "Key events in the individual's life, [that provoke the selection] of particular kinds of actions, [that] in turn lead them in particular directions, and they end up having implications for identity" (as cited in Lengeling \& Mora, 2016, p. 77). CI allows the identification of what Wethington, Clausen, and Cappeliez call, "Changes in individual perception 
about self-identity, life significance and self-concept" (as cited in O'Shea, 2014, p. 5).

\section{Method}

A descriptive case study (Cohen et al., 2007) was set up to examine and interpret the lived experience and the meanings made by a group of $\mathrm{FL}$ preservice teachers during their practicum. The bounded nature of the case assisted in obtaining a rich and vivid analytical description and focused on individual actors to understand their perceptions of events (Cohen et al., 2007). Thematic narrative analysis helped to display the stories that represent how the PSTs made sense of their experiences, communicated with others, and understood the world around them (Merriam, 2009).

\section{Participants}

Eight student teachers in their last semester — four males and four females with ages ranging from 19 to 22- participated in the study. Convenience sampling was used because of the easy access the researchers had to the participants. The practicum lasted 16 weeks ( 4 hours a week) and was developed in a neighboring public school with secondary students. As regards to participants' teaching experience, four had tutored young children, two had had a teaching position for a short period at public and private schools, and two had no experience. Before the practicum, PSTs take 11 courses - Philosophy of Education, Epistemology of Language, Curriculum, Teaching Methods, Contemporary Didactics, Psycholinguistics, Education Laws and Legislation, Cognitive Psychology, and Research Pedagogical Practicum I, II, \& III. None of the mentioned courses address teacher identity explicitly. During the practicum, they met 3 hours a week with a mentor to reflect over their challenges, to discuss pedagogical issues and strategies, to handle different situations and to do research. All participants signed a letter of consent and were given pseudonyms to ensure their anonymity: Raul, Carlos, Mariana, Angela, Delia, Amalia, Gloria and Javier. All except Javier expressed they enrolled in the program with the desire to become a teacher.

\section{Research Context}

The university is the only state university in the city. The Foreign Languages Teaching Program initiated on August 2013 with 45 students who came from low income families and lived either near smaller towns or in marginalized neighborhoods near the university. The school where students did the practicum serves an underprivileged population.

\section{Data collection}

The data were collected over a four-month period in a three-stage process (initial, intermediate and final) and came from three sources: interviews, journals, and drawings. At the beginning, participants were called and asked if they wanted to be part of this research. Once they were informed about the details of this process and it was clearly stated that several steps would be taken to protect their anonymity, they willingly signed a consent letter agreeing on all terms. Pseudonyms were used to ensure participants' confidentiality. Interviews with PSTs explored their thoughts, beliefs, feelings, assumptions, attitudes, perceptions, and experiences. Some of the questions included:(a) What makes you a teacher?, (b)What is a successful teacher?, (c) What is most rewarding about teaching?, (d) What is most challenging about teaching?, (e) How would you describe the emotional aspects of teaching?, (f) What are the big issues for you as a teacher right now?, and $(\mathrm{g})$ in what ways are you happy with yourself as a teacher?

Preservice-teachers kept a reflective journal to record weekly entries in four main aspects: positive aspects of the lesson, challenges faced during the lesson, strategies to overcome those challenges, and feelings towards a particular lesson to allow us to understand how they deconstructed and reconstructed their teaching frameworks. The participants were also asked to make drawings based on a prompt given one week before starting, 
another given mid-practicum, and a final one given at the end (the teacher you want to be; the teacher you are; and the teacher you have become respectively). Additionally, they were asked to provide an explanation giving researchers more insights into their beliefs and perceptions about teaching.

\section{Data analysis}

To analyze gathered data, we used the qualitative software Atlas.ti 7. For the interview data, we grouped the questions into themes related to teaching identity. We analyzed the data to identify possible factors affecting participants' teaching identities. With the initial themes, we then turned to theory about the elements that affected the teaching identity and factors associated with teaching (Beijaard et al., 2004; Gee, as cited in Lerseth, 2013). We assigned 39 codes and identified 305 emerging references. The references were revised until we grouped them into refined themes, which we labeled "identity shaping factors." These factors related to values, to their personalities, to the decision-making process, to the context, to reflection during the practicum and to meaningful events during the process.

For the journals, we aimed at identifying levels of descriptiveness and reflectiveness in the entries. Seventy-two journal entries were analyzed using the chart of Journal Writing Themes (Richards \& Ho, 1993 adapted by Insuasty \& Zambrano, 2010) coded in 287 references from which six categories emerged (theories of teaching, approaches and methods, evaluating and teaching, self-awareness, questions about teaching, and student teacher's feelings). In a second round of analysis, we cross-examined their entries to get insights into other components of their reflection. The references derived from the journals were triangulated with the ones from the interviews, which enriched previously identified factors.

The analysis of PSTs' drawings and their descriptions aimed at identifying aspects of their self-image and their relationships with teaching.
They provided data about other identity shaping factors that could not be accessed through more traditional instruments. Some of the codes from the interviews resonated with their drawing descriptions. We triangulated this analysis with the other identity factors from analyzed data. After the different rounds of analysis, there emerged six main identity factors which we present in the findings section.

\section{Findings}

This study examined the factors that shaped the identity of a group of FL preservice teachers studying at a language teacher education program in a Colombian state university. The most notable factors were value and belief system, personality traits, pedagogical decisions, context, reflective practice, and critical incidents.

\section{Value/Belief System}

108 references out of 305 from the data were related to student teachers' values or beliefs, making this the most recurrent factor. Preservice teachers' pre-existing beliefs about desired teaching, desired learning, and themselves were linked to what a teacher is and the ones regarding actual teaching and learning practice were classified as what a teacher does. Similarly, the ethical values that the participants brought to the practicum were linked to what a teacher is, whereas the ones that they fostered throughout their practicum experience at school were labeled as what a teacher does. Beliefs and values about what the teacher does are more frequent than those about what a teacher is in the three stages of data collection. Preconceptions were more frequent at the intermediate stage of the practicum and decreased a little towards the end (see a summary of identified values and beliefs in Appendix 1).

The analysis of the drawings showed a change in perspective in all participants from a romantic perception of teaching to a disenchanted view. Issues that affected their perceptions included pupils' 
misbehavior, lack of motivation, and negative attitude towards the class. Figure 2 shows the drawings done by Angela before starting (left panel) and in the second stage of the practicum (right panel). The left panel represents Angela's beliefs that she would plan fun and active lessons in which students would feel motivated to learn and that she would be a happy teacher. Under the right panel she wrote:

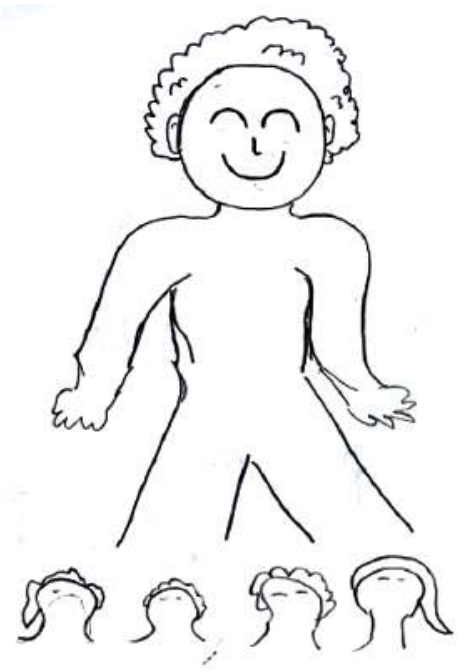

In the intermediate stage of the practicum, all PSTs agreed that being a teacher implies academic competencies as well as other life abilities to help them succeed inside and outside the classroom. Likewise, seven of them wanted to learn strategies to handle their struggles at school, such as forging strong relationships with students to motivate them and adopting a more tough-love approach to discipline. Participants were constructing new beliefs that learning new strategies would help
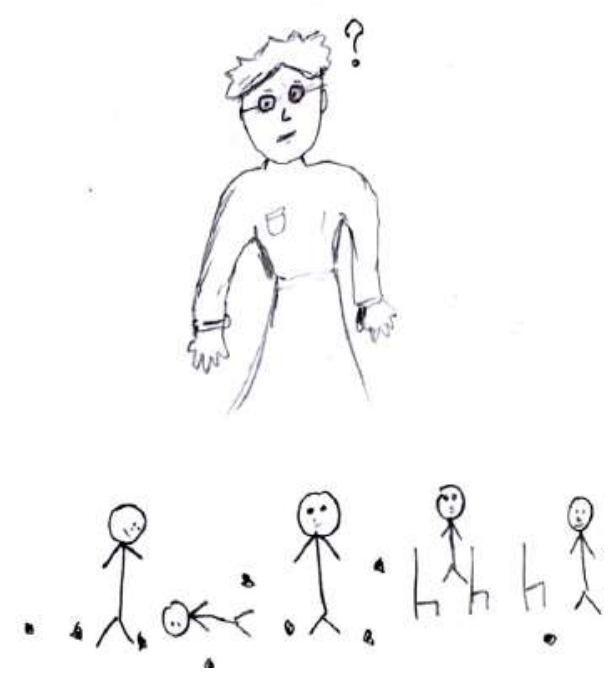

Figure 2 Angela’s Case: Comparative Drawings of Metaphors

Note: Drawings of Angela's feelings at the initial stage (left panel) and the intermediate stage (right panel)

There are like six students that are always misbehaving. Always! And they do nothing. They don't respect me, don't respect the other teacher. They don't care about the grades and anything... When things go wrong, I desperate easily and I don't know how to handle it. I get like anxious and angry and mad and yelling. (Drawing, May 14, 2017)

The analysis of interviews provided complementary data about how participants' prior beliefs started fading once they began to encounter problems in the classroom. They often seemed to feel unprepared to address problems, and the confusion and frustration made them doubt themselves as teachers. In the first stage, the participants were somehow merging their past experiences with their present teaching experience to consolidate a concept of what it meant to be a teacher. them become better versions of their "teacher selves" and, consequently, forging future trajectories for their teacher identity.

Gloria, on the contrary, was convinced that she had no control over the circumstances and refused to accept the school reality. She felt that trying out new strategies was pointless. Gloria expressed:

I have some students, some girls that when they see me, they are like: Umm! Making a bad face. And I feel so bad because some of them are not motivated at all. And it hurts, it hurts me somehow. (Interview, May 14, 2017).

It seems that for Gloria, being a teacher was a matter of giving and receiving. Reciprocity from her students was essential for her to be able to 
formulate a future trajectory in her becoming a teacher. Without that reciprocity, Gloria preferred to avoid getting more involved in the process.

In a similar line, Javier concluded that the practicum had reinforced his decision to not become a teacher. This last case, of dropout behavior, uncovers a reality that teacher education programs face retaining and preparing preservice teachers for the challenges of the context. Javier became aware of the multiple aspects that affected his identity and his role in the school and the society. He could not stand the social and institutional forces he was subjected to.

By the end of the practicum, data showed most participants evaluating their personal values and referring to the importance of practicing compassion, kindness, tolerance, and love inside the classroom. They felt those values should exist as part of their teacher and personal selves and sought to make changes as a strategy to become better teachers. Participants' priorities shifted to emphasize caring about their students' family, financial, and emotional issues. They started to make decisions about the person they needed to be to build better relationships with their students. They perceived their process as the beginning of a long journey of discovery in which, more than having definite and rooted ideas about learning and teaching, they expect to find answers for How questions (e.g., how to help students learn English, how to be an original teacher, and how to be a good teacher). Our data showed participants constructing their teacher identities as stories that can be reconstructed over time through questioning and the identification of challenges.

\section{Personality Traits}

There were 23 references related to the personality traits that participants discovered or built inside the classroom during their practicum (labeled "character in") and 21 references linked to traits they already had, which contributed or conflicted with their teaching experience (labeled "character out"). Analysis shows that these PSTs developed needed personality traits to enhance their teaching practice, their relationship with the pupils, and the ambiance of the classroom as they progressed in their practicum (see a list of personality traits in Appendix 2).

During the practicum, there was an evident interplay between their pre-existing personality traits and that of their students. PSTs found some traits were advantageous (e.g., friendly, funny, outgoing, creative, caring) and facilitated their rapport with the students and pupils' engagement in class. Andrés' comment illustrates this: "Surprisingly, I think I am creative (everybody laughed) because I am not teaching like in a traditional way. I try to design posters, slides (Interview, Feb 14, 2017)”. They also perceived that some traits were troublesome (lack of authority, unpassionate, unfriendly, impatient). Delia, for instance, said:

My temper or my mood is affecting my classes because sometimes I get angry and I just you know show that, that anger to my students [...] and I raise my voice $[. .$. and they show, they show with their faces that they don't like it. (Interview, May 14, 2017)

The data suggest that the students our participants had in mind, before their practicum, resembled abstract homogenized beings that could fit into the profile of a universal student. Over time, they realized that their classrooms were full of human beings with different life stories. This realization led them to attempt to reconstruct their identity through a more caring relationship with their students. This career role that the PSTs were assuming left them in a position in which they were no longer the center of the process. Now, their students were the center. Carlos, for example, remarked: "The only thing that matters is the relationship between you and the student (Interview, May 14, 2017)”.

At the end of the process, participants identified some desirable interpersonal attributes and tried to develop and exhibit them in the classroom to be recognized as excellent teachers by others (e.g., 
tolerance, confidence, sensitive, willingness to help). Mariana's statement evidenced some of this.

I learned that we have to be a little bit more sensitive and try to understand a little bit people's lives and what they are facing since we don't know. My students, they have a lot of problems and once I was like thinking about that, why they act like that, why they behave like that and I realize that maybe that I know what they do, but I don't know if they are facing problems at home. We should like try not to judge people, maybe to understand them. (Interview, June 24, 2017).

They made specific efforts to build and strengthen a relationship with the students, to connect to others at school. Those connections with more experienced teachers, for example, influenced their practice. Delia expressed it like this:

There are so many things I have to improve. With the cooperating teacher I have learnt how to deal with some situations and I have learnt some strategies that have helped me a lot. So, I have improved, and I have learnt new things I didn't know, so yes relations have helped me a lot. (Interview, June 24, 2017)

Relationships with experienced teachers enhanced their awareness that supporting students and constructing teaching in ways that went beyond the actual delivery of the curriculum was a choice.

\section{Pedagogical Decisions}

The analysis of the data from the interviews and drawings unveiled six sub factors with 51 references (out of 305) linked to teaching challenges, students' success, students' problems, students' needs, and societal issues (see a summary of pedagogical decisions themes in Appendix 3).

At the beginning, participants were concerned with decisions related to daily teaching challenges, students' difficulties in learning the language, and students' success in class. The most noticeable student-related problem was student disengagement in class: "When I started to teach them, I realized that half the students are the ones who are interested in the class, to learn English, and the majority of them don't like to pay attention or participate" (Andrés, Interview, Feb 14, 2017). They had a genuine interest in helping learners succeed despite adverse circumstances in their teaching contexts. They had ideas about what students should know about the language and noticed the gap between this goal and the limitations of the school in terms of resources.

In the intermediate stage of the practicum, there was a persistent confrontation between their content knowledge and the manner of putting that knowledge in terms their students could understand. They went to the practicum with this sensation of having knowledge which needed to be poured out, but they did not know how to do it effectively; they felt a disconnect between what they imagined the experience would be like and the actual practices. Delia expressed how she had pictured herself speaking English all the time in class and discussed what actually happened.

They are not used to the language and I didn't know that. I start (sic) speaking English the whole time because I saw that that day they were going to like: We know that. But they don't. So, I have problems with the target language use in the classroom. (Interview, May 24, 2017)

The imagined identities and communities created by our participants before the practicum, did not match their real classroom contexts. That disconnect can be perceived in some of the drawings from stage 2. Figure 3 illustrates how Gloria (left panel) and Mariana (right panel) experienced that lack of alignment along with a sense of adversity and hardship. Their drawings metaphorically embody teaching as being hard and problematic.

Gloria's smiley teacher, for example, has an F on her mind as a synonym of "failure," as the participant explained. Whereas, Mariana's drawing reflects that there were dilemmas related to students' apparent reluctance to learn and to other language-related issues. Gloria remarked: “They cannot understand when I speak in English. Even 

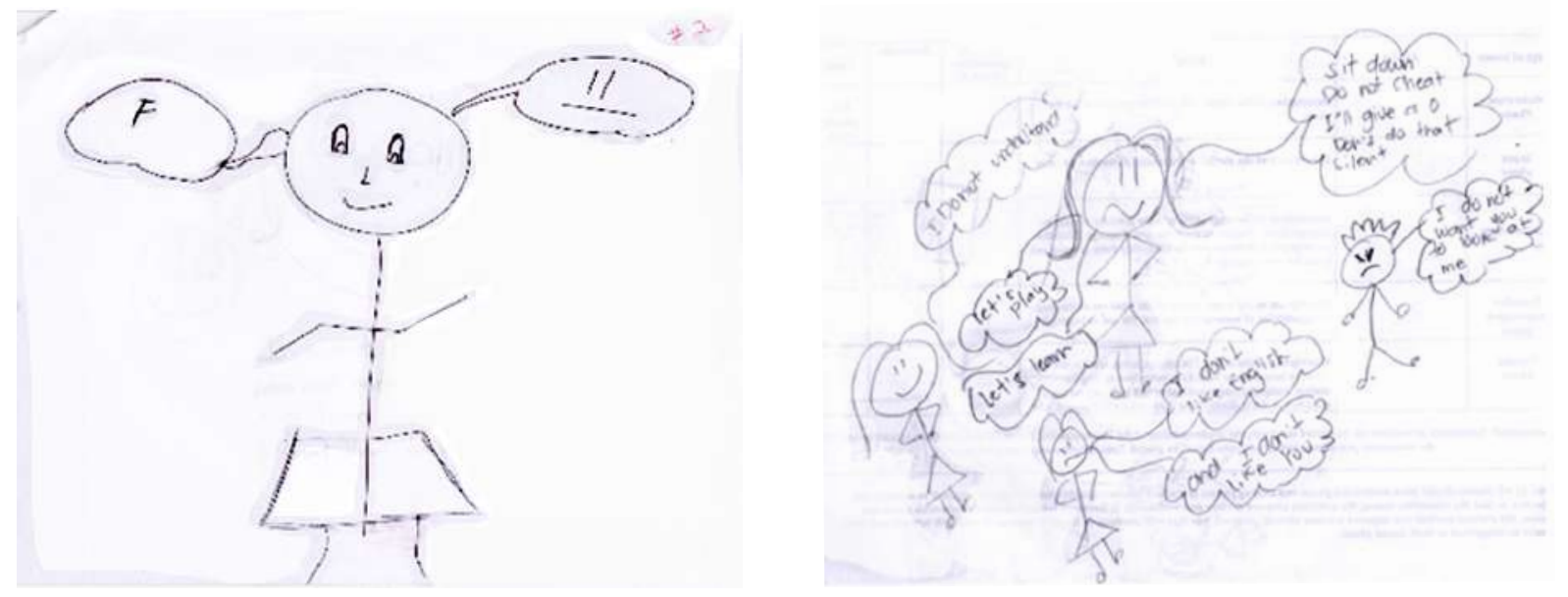

Figure 3 Intermediate Stage: Comparative Drawings of Metaphors

Note: Drawings of "metaphor number 2" by Gloria (left panel) and Mariana (right panel). They were drawn after 2 months into their practicum and depicted an overwhelming feeling of failure and chaos.

when I try to speak very slow and I try to like use a very simple vocabulary, but they still have learning problems and they are students of 11 th grade" (Drawing, May 14, 2017). During the interviews, Carlos also mentioned his students' reluctance to learn as opposite to what he had in mind before his practicum: "It doesn't matter what I say to them, they just say, I'm not going to participate. And I don't know what to do with them because they should be learning too" (Interview, May 14, 2017). Data suggest that there was a persistent tone of frustration among the participants because they had assumed that students would assuredly learn, after as teachers, they had done what they were supposed to do.

This affected their identity; they seemed to believe that the more the students learned the better they were as teachers. Their concerns about their students' learning process showed how they expanded their role to include a concern for their students' needs, subsequently transforming their identities.

\section{Context}

The context factor included 26 references to situations related to the classroom, colleagues, practicum (the actual training sessions) and school authorities which we linked to the what-a-teacher-does category and 4 references to situations related to family, friends and school which we linked to the what-a-teacher-is category.

At the beginning, references related to dealing with learners for the first time and issues like time management, misbehavior, bullying, seating arrangements and how classroom conditions troubled them.

The time of the class, it's not enough. Only 50 minutes that seem 40 or 30 minutes. I have 41 , now 42 students because yesterday another one came. Also, the classroom is hot. So, I have felt a bit uncomfortable.

(Andrés, Interview, Feb 21, 2017)

As the preservice teachers did not know how to interact with their students or read the conditions around them, they felt insecure and threatened as they were trying to get accustomed to their surroundings.

Participants faced difficulties dealing with their students; therefore, solving these issues became important, and so did the practicum instruction sessions where they consulted their teachers about the complications they were experiencing. The relation with their students and the physical ambiance affected their idea of teaching and took a toll on their expectations as they had trouble adapting. The participants needed confidence 
and reassurance, so they relied on the more experienced teachers to develop that sense of professional agency. Javier's quote on the reassuring connection illustrates this: "Clara my supervisor. She is so nice. The day I did something that went wrong I just messaged her and I was so desperate. This happened and she said: Don't worry! Its fine and she just motivated me" (Interview, May 14, 2017). Challenging classroom situations and teachers with expertise comprise a part of what context is. That symbiotic relationship influenced and shaped their identity. By the final stage, participants referred less to context, but they emphasized the lack of resources and the heavily crowded classrooms.

\section{Reflective Practice}

This category results from the analysis of participants' reflections evidenced in their journal entries and interviews. The most recurrent issues were concerned with "evaluating teaching" (221 out of 287 references). Participants assessed their classes in terms of students' motivation to learn, participation, behavior, topic understanding, attention, and willingness to do class activities. Raul, for instance, remarked: "The challenge I faced this week, was to have a control of my class because most students were stood (sic) all the time, while some others were talking to their classmates" (Journal, Feb 6, 2017).

In their journal reflections, there were attempts to gain a more in-depth understanding of the principles and reasons behind their lesson plans and actions inside the classroom. They deconstructed their practice and started to articulate their personal practical theories. They not only diagnosed problems concerning themselves, their students, the school context, and classroom interaction, but also proposed strategies to solve them ( 46 references out of 221).

The construction of personal practical theories among the participants was evident in terms of language learning and classroom management.
For instance, Raul explained his decision to make small groups in order to have students work and share knowledge together based on the premise that group work and cooperative learning was good for language acquisition. While Andrés, for example, concluded that modeling the use of language was more effective for students' understanding, Mariana remarked that "practice opportunities should be given to students to learn a topic" (Journal, April 26, 2017). In the same way, Delia established that "exams and quizzes make students quiet" (Journal, March 2, 2017). Our data suggest that reflection, even when it is just a self-examination, can still make way for preservice teachers' reconfigurations of their identities.

\section{Critical Incidents}

The critical incidents analysis suggested similarities regarding areas of the identity they were reconstructing, as well as differences in the moments in which they experienced such shifts. Figure 4 presents a summary of the critical incidents and the factors that shaped their identity (context, value/belief system, pedagogical decisions, personality traits, reflective practice). As observed, reflective practice and value/belief system are factors that have a greater frequency and probably greater effect on preservice teachers' identity.

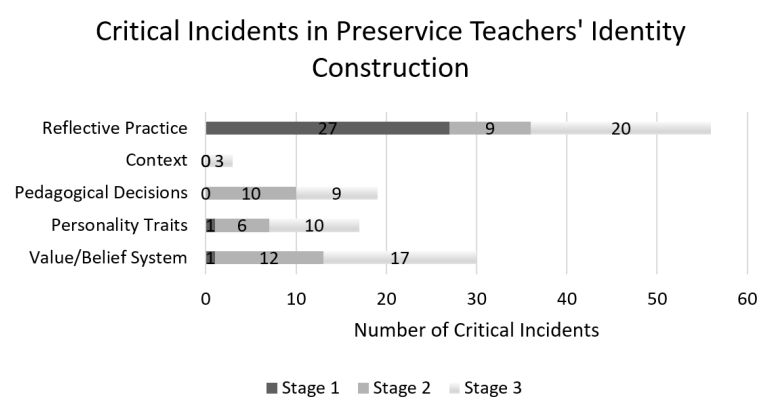

Figure 4 Critical Incidents in Preservice Teacher's Identity Construction

Note: Number of critical incidents that preservice teachers presented belonging to the five identity factors revealed in the study throughout the three stages of their first practicum. 
Preservice critical incidents related to reflective practice showed participants constructing personal practice theories about classroom management and language learning (see Reflective Factor section). Critical incidents about participants' beliefs and values were related to the complexity of teaching, the importance of students' family and financial backgrounds, the need of specific values, and the implications of students' misbehavior and demotivation in language learning. As mentioned before, preservice teachers reported the emerging belief that teaching goes beyond content knowledge by implying care, guidance, and relationship building.

Similarly, critical incidents about their personality traits evidenced that they did not believe in a fixed teacher mold but in adaptability: every experience in the classroom was an opportunity to reinvent themselves and become aware of the different roles they could play in the classroom. During the second and final stages of the practicum, participants incorporated facets of parent, counsellor, teacher, protector, helper, and co-worker. PSTs' remarks revealed that shifts in their personality mainly emerged as a response to the link between school, family adversities and students' externalizing behavioral problems (see Context section).

Figure 4 depicts that, in relation to pedagogical decisions, shifts were evidenced in later stages. During the initial stage of the practicum, the participants appear not to have space or time to reflect but merely "cope" and get through the day. But during the intermediate and final stages, modifications appeared in terms of classroom management, teaching strategies, understanding students, and teaching methodology. Carlos' comment below illustrates his movement from preservice teacher to teacher:

I didn't know there were so many things that you have to take into account when teaching someone. I thought I was going to only stand in front of the board and start talking. But I started talking with all these people [cooperating teacher and supervisor] about teaching and I started to change the way teaching meant to be done. (Interview, June 24, 2017)

Participants' choices during these stages helped to strengthen their teaching identity, the "continual flux" (Izadinia, 2013) and dynamism of becoming teachers.

For the context factor, the data revealed critical incidents during the final stage around a rooted theme: the reality in public schools. For instance, Javier changed the perception he had of publicschool teachers. In the end, he had a more positive attitude towards their work and a more critical attitude towards the educational system. This implies that he moved from idealizing teachers to a survival phase in a public-school context which consumed his energy; and from there, to a disillusionment phase when he emphasized on public schools lacking the minimum elements required to teach, resulting in an educational system with disinterested students. Data showed preservice teachers having little or no control over their surroundings, as if they could do nothing to transform the conditions. This suggests their need for reconciliation with the external world through the acceptance of the context.

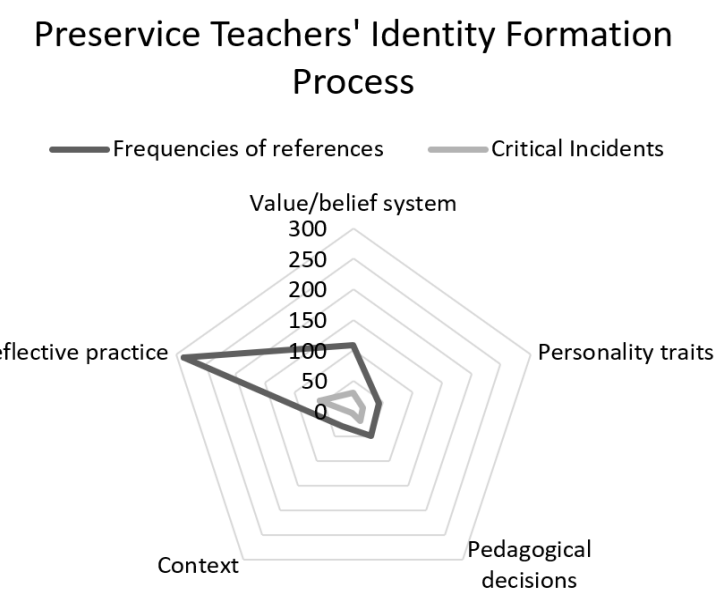

Figure 5 Influence of Each Identity Factor by Number of Ocurrences

Note: Radar chart showing the influence of each identity factor by number of occurrences. 
Data presented thus far show that the factors identified in this study influence PSTs' identity construction. Data also indicate that changes in identity happen at a very slow rate. As it is depicted in Figure 5, although PSTs often reflected on their classroom experiences and frequently referred to factors such as values, beliefs, personality traits, pedagogical decisions, and context, only a small number of these references turned into a critical incident that eventually appears to have caused a change in their teacher identity.

\section{Discussion and Conclusions}

In this study, we aimed to explore the factors that shaped the identity of a group of FL preservice teachers studying at a language teacher education program in a Colombian state university. The study identified six main factors: value and belief systems, personality traits, pedagogical decisions, the context, the reflective practice, and critical incidents.

These six factors were noticeable during the practicum and constantly regulated and shaped PSTs' ongoing identity configuration. In general terms it can be stated that, on the one hand, these factors shaped their identities since they triggered emotional responses, made them challenge themselves, allowed them to face dilemmas, forced them to deal with conflicts, made them feel tension and question themselves permanently. On the other hand, these factors forced them to develop adaptations to the contexts, building relationships and positioning themselves in such contexts by deconstructing their practice. These factors influenced the process of identity reconfiguration they went through.

It was evident in our study that identity configurations of PSTs are affected by the clash between present and imagined identities. For instance, current idealistic perspectives of teaching among PSTs appeared to be a crucial aspect when moving from student to teacher role; we detected three distinct moments in our study. First, there was a clash between their imagined identities and their practiced ones as they navigated the "conflicting worlds, the gap between their expectations and the reality shock they experience when they eventually begin teaching" (Friedman as cited in Beltman et al., 2015, p. 227). As discussed by Xu (2012), their practicum experiences helped them to confront their imagined identities and their practiced identities and forced them somehow to revisit and align them.

In a second moment, PSTs felt afflicted when they demonstrated a lack of teaching competence and experienced a disconnect "between theory and practice" (Russell et al., as cited in Lerseth, 2013, p. 1). It is worth noticing that our participants assume the gap between theory and practice as their inability to translate the knowledge received from others throughout their teacher education courses into practice. We question if that is what becoming a teacher should be about. Studies (Insuasty \& Zambrano, 2010; Motha et al., 2012) have asserted that there is a clear gap between theory and practice when students start teaching; however, it seems necessary to define what it is understood by "theory." If we understand theory as the governing theories in our profession that are not representative of all individuals and as that which promotes a homogenous teaching force that minimizes or excludes teacher identities, local context realities and local sociocultural knowledges, then teacher educators are called to reevaluate the meaning of theory and the nature of the gap. Implications could be derived for how we strike this balance in teacher education programs.

On a third and ongoing flux during the practicum, participants battled with their identities regarding the, how to act and how to be. This somehow led them to "understand their work and place in society [,] given that it is negotiated through experience and the sense that is made of that experience" (Sachs as cited in Diaz de la Garza, 2017, p. 12). Even though, the "how to" indicates that preservice teachers' professional identity was flourishing as they were involved in the process of 
practice deconstruction and new theory acquisition, an analysis of the nature of these questions becomes relevant. In this regard, Motha et al. (2012) suggest de-emphasizing the so-called "how to" list, full of one-size-fits-all strategies and resources based on standardized steps or magical potions for troublesome classroom situations. Instead, emphasis should be made on "what", "why", and "where" questions. Bartlett (as cited in Insuasty \& Zambrano, 2010), for instance, suggests that shifting to the "what and why questions gives us [more] power over our teaching, and in this way, we can begin to exercise control and open up the possibility of transforming our everyday classroom life" (p. 89).

Attention should be paid to PSTs "imagined identities" (Barkhuizen et al., 2013; Iswandari, 2017; $\mathrm{Xu}, 2013)$ to explore whether those identities are finding a place in the real world. Those imagined identities are idealistic as imagination is endless, while their teaching experience has been limited to their incipient teaching practice. Therefore, preparation for the practicum should provide PSTs scaffolded opportunities to come to terms with, recognize and further analyze the imagined identities that might open other identity options as well as prepare them to critically transition to the real world while accepting, negotiating or resisting imposed identities. Programs should incorporate explicit strategies to help preservice teachers anticipate the upcoming challenges during their practicum and early career years. Further investigating what works best for this purpose could be a way forward.

Based on our study, we confirm that the PSTs' identity formation process cannot be separated from the social and institutional contexts. Identity formation is context-bound. Analyzing their identities in such spaces gives deeper understanding of why they see themselves in a specific way during their practicum. We found adaptations in response to the context: the learners, the surroundings and teaching theories.
In terms of learner-related adaptations, this study made visible the social nature of identity formation in which teachers enrich their personality through relationships with their students. The participants did not only enrich their qualities as humans but acknowledged that their students were real beings with different personalities and backgrounds. The personality reconfigurations made by the participants were intrinsically rewarding for them (Morrison, 2012) and reinforced the role of agency as a central part of identity formation (Bucholtz \& Hall, as cited in Riyanti, 2017). It was evidenced that PSTs developed new personality traits because their students contested their identities. They identified values and personality traits that were advantageous and simultaneously developed new ones that they considered necessary to fit in their classrooms with their students (Morgan, 2004).

In a similar vein, our study confirmed that what a teacher does and the act of teaching itself is mediated by the relationship between the teacher and the students. This shows the importance of social identities and sociocultural perspectives for aspiring teachers. We think language teacher education programs should continue to pose questions such as: Are we helping our preservice teachers construct their social identities? If teaching is so linked to others and society, are we really reflecting on the great diversity of social relationships and what they imply? Is there enough focus on diversity within programs? Are we communicating the complexity; the personal, professional and cultural challenges? (Pennycook, 2004) This is an area for further research.

Additionally, adaptations also emerged as response to the surroundings. PSTs showed dialogical tension with their surroundings in a process of adjustment that required time for them to "adapt their personal understanding to the realities which prevail in the schools where they are placed" (as cited in Rodgers \& Scott, 2008, p. 217). This showed that participants' teacher identity construction is not only negotiated through their inner forces, but other 
external ones such as social and classroom contexts that affect who they are as teachers and what they do at specific moments of their teaching experience (Arrieta \& Rosado, 2020). The fact that the participants relied on the more experienced teachers to overcome the challenging classroom situations highlights that collaboration between inexperienced and experienced teachers helps PSTs construct their identity by sharing experiences and knowledge. This supports scholarship on the crucial role of communities to facilitate the transition of novices into a given community of practice.

There were two interesting cases concerning PSTs' agency in identity configuration. Our participants faced challenging scenarios which brought about adverse responses. One participant decided to stop trying to fit the static universal teacher mold implicitly presented to her in the program, evidencing that attention to identity formation could open PSTS' mind to more realistic expectations and pragmatic solutions to address them prior to entering the classroom. Once preservice teachers have direct interaction with students and classrooms, they could reinvent themselves and choose the future trajectories that represent their roles not only as teachers, but as human beings too.

Goodson and Gill (2008) assert that identity is subject to "a sense of oneself that is more autonomous and enduring" (p. 121) and that a narrative can, to some extent, empower an individual "to begin to choose a life trajectory more in tune with his/her own nature, identity and perception of his/her purpose in the world" (p. 121).

The other case was one participant's dropout behavior as a result of the practicum experience, which we related to Hong's view (2010) that PSTs' naive perspectives on teaching cause an emotional burnout that eventually is the leading factor for dropout. This author suggests that teaching programs should avoid allowing novice teachers to "leave their professional training with their idealistic perspectives" (p. 1540). Both cases reinforce the idea that identity construction implies choice; a person can autonomously choose a future trajectory that goes more hand in hand with his perception of self.

Our study suggests that PSTs' identity formation cycles back between what has been reflected and theorized in a teacher education program, and their own teaching experience. This interplay appears to allow for transformations in their identity. Here, we understand transformations as personal practical theories that were generated, modified or consolidated. This study shows that participants constructed their own personal practical theories and supports scholarship that shows that theories are "blended by the personal background and characteristics of the teacher and expressed by the teacher in particular situations. They guide the teacher's work, action, and reactions before, during, and after a teaching event, and can be articulable" (Maaranen \& Stenberg, 2017, p. 2).

Likewise, PSTs that are able to reflect and take action afterwards, are constructing their understanding of who they are within the classroom. Diaz de la Garza (2017) highlights that actions based on reflections usually "feed back into the ongoing identity construction process as they develop and refine their personal philosophies related to their developing selves and careers" (p. 250). Besides, PSTs construction of personal teaching theories show that language teacher education programs are called to recognize teacher candidates as individuals able to become contributors instead of just being borrowers of governing and global theories in the field. This is an area worth exploring in further research.

Through reflection, PSTs appeared to strengthen, negotiate, contest or transform aspects of their identity. One implication is that reflection for identity construction should be done purposefully (Korthagen as cited in Diaz de la Garza, 2017; Kumaravadivelu, 2001), especially during the practicum. Currently, teacher identity pedagogy is sidelined in the curriculum in language teacher education programs; therefore, teacher candidates still 
find it unnatural to question themselves, their ways of teaching and their identities. Darvin and Norton (2015) assert that "by raising questions about their own ways of thinking of the status quo [...] learners may not only participate in but also transform the multiple spaces of their life worlds" (p. 47), moving beyond essential personal introspection towards a continued awareness that acknowledges socio-political issues and therefore transcends the classroom. Implications for reflective opportunities concerning identity construction before and during the experience should be considered.

In our study PSTs' identities were influenced by six factors that triggered development of interpersonal relationships, a quality-based category. In contrast, a study by Hammon et al. (2010) found preservice teachers appeared to be more concerned with the task-based categories (classroom management and instruction) whereas in-service teachers identity has to do with quality-based categories (interpersonal relationships and professionalism). They add that teacher preparation programs should consider that apparent linear development when choosing the contents of the coursework. This suggests that teacher education programs should consider carefully what and when to address different aspects of identity since findings in this regard are not conclusive.

Our study indicated that changes in identity happen at a very slow rate suggesting that identity formation in PSTs does not necessarily mean a constant shift in their stories. Our PSTs reflected on their classroom experiences and referred to events related to values, beliefs, personality traits, pedagogical decisions, and context; but in the end, only a small number of those events turned into a critical incident that appears to have caused a change in their teacher identity. Therefore, we learned that, for our participants, identity seemed to be constructed through the intersection between the different experiences they went through during their practicum and their past and future trajectories. Those intersections did not necessarily imply constant or big changes; instead they referred to an aspect that was strengthened during the experience and that facilitated the student teacher understanding of him/herself.

We found that PSTs' adaptability was a great asset; however, a critical stance should accompany changes. In this regard, Morgan (2004) states that teacher education programs need to equip PSTs with the necessary tools to be able to recognize situations or "texts" and develop decision-making skills. Such skills could help them detect what should or should not be accepted, but instead negotiated or resisted. There is a need to tackle identity pedagogy explicitly in language teacher education programs because PSTs are already using it for pedagogical purposes. If more importance is attached to identity construction processes in teacher education, there may be a possibility of "lessening the distance between teacher education programs and student teachers' lives" (Motha et al., 2012, p. 15). Teacher education programs should provide PSTs intentional opportunities to engage in "dialogical spaces where students (preservice teachers) can negotiate power relations and position themselves as agents of their own ongoing identity construction processes" (Arrieta \& Rosado, 2020, p.404).

In the same line, teacher education programs are called to purposively integrate preservice teachers' knowledges, beliefs, values, and insights as valuable knowledge into the teaching process. A teacher education program should recognize what they already bring with them from a bottom-up perspective. Programs should recognize the well-known "grand metanarratives" (Lyotard, 1997), but also integrate and embrace local, bottom-up knowledges. This implies endorsing the idea that teacher candidates should value the knowledge of teaching that comes from others as well as the knowledge of teaching that emanates within themselves (Motha et al., 2012), their practice and communities.

In a closing note, studying the process of preservice teacher identity configuration in the making (complex, dynamic/fluid, individual/social) was very revealing. 
One question that arises as we finish this report is the possibility of relating the content of our teacher education curriculum to PSTs' identity configurations. This could be explored in further studies. Due to the localized nature of this case study, aspirations of generalizations are limited. However, the factors identified in our study could resonate to researchers or teacher educators in similar contexts. In our context, identity pedagogy is not addressed explicitly in the curriculum. Results from this study will allow us to incorporate it. We suggest PSTs' identity configuration could be strengthened through the explicit incorporation of identity pedagogy in this and other teacher education programs.

\section{References}

Akcan, S. (2016). Novice non-native English teachers' reflections on their teacher education programmes and their first years of teaching. PROFILE: Issues in Teachers' Professional Development, 18(1), 55-70. https://doi.org/10.15446/profile.v18n1.48608

Akkerman, S., \& Meijer, P. (2011). A dialogical approach to conceptualizing teacher identity. Teaching and Teacher Education: An International Journal of Research and Studies, 27(2), 308-319. https://doi. org/10.1016/j.tate.2010.08.013

Arrieta, A. \& Rosado, N. (2020). Complex identities through positionings in ongoing interaction: A case study in a foreign language teacher education program in Colombia. In N. Rudolph, A. F. Selvi, \& B. Yazan, (Eds.), The complexity of identity and interaction in language education. Multilingual Matters.

Barkhuizen, G., Benson, P., Bodycott, P., \& Brown, J. (2013). Second language identity in narratives of study abroad. Palgrave Macmillan.

Beijaard, D., Meijer, P., \& Verloop, N., (2004). Reconsidering research on teachers' professional identity. Teaching and Teacher Education, 20(2), 107-128. https://doi.org/10.1016/j.tate.2003.07.001

Beltman, S., Glass, C., Dinham, J., Chalk, B., \& Nguyen, B. (2015). Drawing identity: Beginning preservice teachers' professional identities. Issues in Educational Research, 25(3), 225-245. http://www.iier.org.au/ iier25/beltman.pdf

Bucholtz, M., \& Hall, K. (2005). Identity and interaction: a sociocultural linguistic approach. Discourse Studies, 7(4-5),
585-614. http://bucholtz.linguistics.ucsb. edu/sites/secure.lsit.ucsb.edu.ling.d7_b/files/ sitefiles/research/publications/BucholtzHall2005DiscourseStudies.pdf

Castañeda, J., \& Aguirre, A. (2018). Preservice English teachers' voices about the teaching practicum. HOW, A Colombian Journal for Teachers of English, 25(1), 156-173. https://doi.org/10.19183/how.25.1.420

Castellanos, J. (2013). The role of English preservice teachers' beliefs about teaching in teacher education programs. Profile: Issues in Teachers' Professional Development, 15(1), 95-206. https://revistas.unal.edu. co/index.php/profile/article/view/37878

Chong, S., Low, E., \& Goh, K. (2011). Emerging professional teacher identity of preservice teachers. Australian Journal of Teacher Education, 36(8), 50-64. https:// files.eric.ed.gov/fulltext/EJ937005.pdf

Clift, R., \& Brady, P. (2005). Research on methods courses and field experiences (pp. 309-422). In M. CochranSmith \& Z. Kenneth (Eds.), Studying teacher education. The report of the AERA panel on research and teacher education. Lawrence Erlbaum Associates, Inc.

Cohen, L., Manion, L., \& Morrison, K. (2007). Research methods in education. Routledge Books.

Darvin, R. \& Norton, B. (2015). Identity and a model of investment in applied linguistics. Annual Review of Applied Linguistics, 35, 36-56. 10.1017/ S0267190514000191

Díaz de la Garza, A. (2017). The emerging identity of preservice teachers during the practicum component of second language teacher education [Doctoral dissertation, University of Southampton]. https://eprints.soton. ac.uk/411892/

Fajardo, J. (2014). Learning to teach and professional identity: Images of personal and professional recognition. PROFILE: Issues in Teachers' Professional Development, 16(2), 49-65. https://revistas.unal.edu.co/ index.php/profile/article/view/38075/47712

Goodson, I. \& Gill, S. (2008). Narrative pedagogy: Life history and learning. Peter Lang.

Guerrero, C., \& Meadows, B. (2015). Global professional identity in deterritorialized spaces: A case study of a critical dialogue between expert and novice nonnative English speaker teachers. PROFILE: Issues in Teachers' Professional Development, 17(2), 13-27. http://dx.doi.org/10.15446/profile.v17n2.44194

Hamman, D., Gosselin, K., Romano, J., \& Bunuan, R. (2010). Using possible-selves theory to understand the identity development of new teachers. Teaching 
and Teacher Education, 26(7), 1349-1361. 10.1016/j. tate.2010.03.005

Heikonen, L., Pietarinen, J., Pyhältö, K., Toom, A., \& Soini, T. (2017). Early career teachers' sense of professional agency in the classroom: Associations with turnover intentions and perceived inadequacy in teacherstudent interaction. Asia-Pacific. Journal of Teacher Education, 45(3), 250-266.

Ho, B., \& Richards, J. (2008). Reflective thinking through teacher journal writing. http://sunzi1.lib.hku.hk/ hkjo/view/10/1000060.pdf.

Hong, J. (2010). Preservice and beginning teachers' professional identity and its relation to dropping out of the profession. Teaching and Teacher Education, 26(8), 1530-1543. https://doi.org/10.1016/j. tate.2010.06.003

Insuasty, E., \& Zambrano, L. (2010). Exploring reflective teaching through informed journal keeping and blog group discussion in the teaching practicum. PROFILE: Issues in Teachers' Professional Development, 12(2), 87-105. https://revistas.unal.edu.co/index. $\mathrm{php} / \mathrm{profile} /$ article/view/17682

Iswandari, Y. (2017). Revealing preservice foreign language teachers' imagined professional identity in reflective journals. Language and Language Teaching Journal, 20(1). 59-67. https://doi.org/10.24071/ llt.2017.200107

Izadinia, M. (2013). A review of research on student teachers' professional identity. British Educational Research Journal, 39(4), 694-713.

Kohli, R., Picower, B., Martinez, A., \& Ortiz, N. (2015). Critical professional development: Centering the social justice needs of teachers. International Journal of Critical Pedagogy, 6(2), 7-24. http://libjournal. uncg.edu/ijcp/article/view/1057

Korthagen, F. (2004). In search of the essence of a good teacher: towards a more holistic approach in teacher education. Teaching and Teacher Education, 20(1), 77-97. https://doi.org/10.1016/j.tate.2003.10.002

Kumaravadivelu, B. (2001). Toward a postmethod pedagogy. TESOL Quarterly, 35(4), 537-557. http://dx.doi. org/10.2307/3588427

Kumaravadivelu, B. (2012). Language teacher education for a global society: A modular model for knowing, analyzing, recognizing, doing, and seeing. ESL \& Applied Linguistics Professional Series. Routledge.

Lengeling, M., \& Mora, P. (2016). Reflections on critical incidents of EFL teachers during career entry in Central Mexico. HOW, A Colombian Journal for Teachers of
English, 23(2), 75-88. http://dx.doi.org/10.19183/ how.23.2.158.

Lerseth, K. (2013). Identity development among preservice teacher candidates [Doctoral dissertation, Iowa State University, Ames, Iowa]. https://lib.dr.iastate. edu/etd/13200/https://lib.dr.iastate.edu/cgi/viewcontent.cgi article $=4207 \&$ context $=$ etd

Lyotard, J-F. (1997). The postmodern condition: A report on knowledge [Translated by G.Bennington, \& B. Massumi]. University of Minnesota.

Maaranen, K., \& Stenberg, K. (2017). Portraying reflection: The contents of student teachers' reflection on personal practical theories and practicum experience. Reflective Practice, International and Multidisciplinary Perspectives, 8(5), 699-712. https://doi.org/ $10.1080 / 14623943.2017 .1323729$

Macías, D. F., \& Sánchez, J. A. (2015). Classroom management: A persistent challenge for preservice foreign language teachers. PROFILE: Issues in Teachers' Professional Development, 17(2), 81-99. https://doi. org/10.15446/profile.v17n2.43641

Mahboob, A. (in press for 2016). Recognizing the local in language teacher identity. In G. Barkhuizen (Ed.), Reflections on language teacher identity. Routledge.

Merriam, S. (2009). Qualitative research: A guide to design and implementation. Jossey-Bass.

Morgan, B. (2004). Teacher identity as pedagogy: Towards a field-internal conceptualization in bilingual and second language education. International Journal of BilingualEducation and Bilingualism, 7(2), 172-188. https://doi.org/10.1080/13670050408667807

Morrison, C. (2012). I've got my degree and teacher registration but where do I get my professional identity? [Doctoral dissertation, University of South Australia]. https://find.library.unisa.edu.au/primo-explore/ fulldisplay?docid=UNISA_ALMA5111187341000 1831\&vid=ROR\&sortby=rank\&lang=en_US

Morrison, C. (2013). Teacher identity in the early career phase: Trajectories that explain and influence development. Australian Journal of Teacher Education, 38(4). http://dx.doi.org/10.14221/ ajte.2013v38n 4.5

Motha, S. Rashi, J. \& Tecle, T. (2012). Translinguistic identity-as-pedagogy: Implications for language teacher education. International Journal of Innovation in English Language Teaching, 1(1), 13-28.

Murphy, J. (2001). Reflective teaching in ELT. In M. CelceMurcia (Ed.), Teaching English as a second or foreign language (pp. 499-515). Heinle \& Heinle. 
O'Shea, S. (2014). Transitions and turning points: $\mathrm{Ex}$ ploring how first-in-family female students story their transition to university and student identity formation. International Journal of Qualitative Studies in Education, 27(2), 135-158. 10.1080/09518398.2013.771226

Pennycook, A. (2004). Critical moments in a TESOL practicum. In B. Norton and K. Toohey (Eds.), Critical pedagogies and language learning (pp. 327-345). Cambridge University Press.

Pinzón, S., \& Guerrero, C. (2018). Living the teaching practicum within dichotomies: The story from within when implementing ICTs in the English language classroom. HOW, A Colombian Journal for Teachers of English, 25(2), 69-89. https://doi.org/10.19183/ how.25.2.459.

Quintero, A. (2016). Creating a pedagogical space that fosters the (re)construction of self through life stories of preservice English language teachers. HOW, A Colombian Journal for Teachers of English, 23(2), 106-124. http://dx.doi.org/10.19183/how.23.2.293

Quintero, A., \& Guerrero, C. H. (2013). "Of being and not being:" Colombian public elementary school teachers' oscillating identities. HOW, A Colombian Journal for Teachers of English, 20(1), 190-205. https://howjournalcolombia.org/index.php/how/article/ view/30

Richards, L. (2009). Handling qualitative data: A practical guide $\left(2^{\text {nd }} E d\right.$.). SAGE
Riyanti, D. (2017). Teacher identity development: A collective case study of English-as-a-Foreign-language preservice teachers learning to teach in an Indonesian university teacher education program [Doctoral dissertation, University of Nebraska]. http://digitalcommons. unl.edu/cehsdiss/289

Rodgers, C., \& Scott, K. (2008). The development of the personal self and professional identity in learning to teach. In M. Cochran-Smith, S. Feiman-Nemser, D. McIntyre \& K. Demers (Eds.), Handbook of research in teacher education (pp.732-755). Routledge Books

Shohamy, E. (2009). Language teachers as partners in crafting educational language policies? Íkala, Revista de Lenguaje y Cultura, 14(2), 45-67

Suárez, S., \& Basto, E. (2017). Identifying preservice teachers' beliefs about teaching EFL and their potential changes. PROFILE: Issues in Teachers' Professional Development, 19(2), 167-184. https://doi. org/10.15446/profile.v19n2.59675

Varghese, M., Morgan, B., Johnston, B., \& Johnson, K. (2005) Theorizing language teacher identity: Three perspectives and beyond. Journal of Language, Identity and Education, 4(1), 21-44. 10.1207/ s15327701jlie0401_2

$\mathrm{Xu}, \mathrm{H}$. (2012). Imagined community falling apart: A case study on the transformation of professional identities of novice ESOL teachers in China. TESOL Quarterly, 46(3), 568-578. https://doi.org/10.1002/tesq.42

\title{
Appendix 1 Summary of values and beliefs displayed by PSTs
}

\author{
1. Students lack motivation to learn English. \\ 2. High rate of misbehavior in public schools. \\ 3. Teaching is complex and implies more than teaching content or having content knowledge. \\ 4. Teaching is about the relationship with the students. \\ 5. Teaching involves caring for and guiding the students. \\ 6. Having a new concept of teaching leads to a modified teaching method. \\ 7. Teaching should be seen as a constant learning process. \\ 8. Learning happens through reflection and subsequent improvement. \\ 9. Teaching is not only based on students' language needs and interests. \\ 10. Teaching is knowing about students' personal lives \\ 11. External factors such as unfavorable work conditions affect teaching. \\ 12. Teachers need to be patient, tolerant, compassionate, kind and caring. \\ 13. Teachers need to acquire knowledge concerning teaching and classroom management. \\ 14. Being a happy teacher is not equal to absence of class rules. \\ 15. Teachers need to help students fall in love with the subject if they want them to learn.
}




\section{Appendix 2 Summary of Personality Traits displayed by PSTs}

\begin{tabular}{|c|c|c|c|}
\hline Criteria & Stage 1 & Stage 2 & Stage 3 \\
\hline $\begin{array}{l}\text { Favorable discovered pre-existing } \\
\text { traits }\end{array}$ & Creativity & & \\
\hline Favorable pre-existing traits & $\begin{array}{l}\text { Being outgoing and funny } \\
\text { Approachable person } \\
\text { Friendly } \\
\text { Flexible with the use of } \\
\text { language } \\
\text { Creative } \\
\text { Caring }\end{array}$ & $\begin{array}{l}\text { Funny } \\
\text { Emotional and caring }\end{array}$ & \\
\hline Unfavorable pre-existing traits & $\begin{array}{l}\text { Lack authority } \\
\text { Get angry easily }\end{array}$ & $\begin{array}{l}\text { Lack authority } \\
\text { Get angry easily } \\
\text { Not friendly } \\
\text { Not passionate }\end{array}$ & \\
\hline Built new traits through the process & $\begin{array}{l}\text { Authoritative } \\
\text { Be angry and yell }\end{array}$ & $\begin{array}{l}\text { Authoritative } \\
\text { Responsible } \\
\text { Punctual } \\
\text { Work collaboratively with } \\
\text { other teachers } \\
\text { Be active }\end{array}$ & $\begin{array}{l}\text { More confident } \\
\text { Sensitive } \\
\text { Responsible } \\
\text { More tolerant } \\
\text { Willing to help } \\
\text { Work collaboratively with } \\
\text { other teachers }\end{array}$ \\
\hline
\end{tabular}

\section{Appendix 3 Summary of pedagogical decisions}

\begin{tabular}{l}
\hline Pedagogical decisions related to \\
\hline Way of teaching \\
Understanding sts attitudes \\
Teaching strategies \\
\hline Teaching methodology \\
Classroom problem solver \\
\hline Teaching methodology \\
Time management \\
\hline Managing bad days \\
Teaching awareness \\
What a teacher does \\
Shape teaching \\
Classroom management \\
Searching for strategies \\
Improving teaching
\end{tabular}

How to reference this article: Buendía-Arias, X. P.; André-Arenas, A.; Rosado-Mendinueta, N-R. (2020). Factors shaping EFL preservice teachers' identity configuration. Íkala, Revista de Lenguaje y Cultura, 25(3), 583-603. https:/doi.org/10.17533/udea.ikala.v25n03a02 